\title{
REDUCTION OF FORMALDEHYDE LEVELS IN TOFU USING WHITE TURMERIC (Curcuma mango) WITH SPECTROPHOTOMETRY
}

\author{
Edy Agustian Yazid ${ }^{1 *}$, Evariza Vyanto Putri² \\ ${ }^{1,2}$ Department of Chemistry, Delima Husada College of Health Analyst, Gresik, Indonesia \\ *Corresponding author: estien_y@yahoo.co.id
}

\begin{abstract}
Tofu is a type of traditional food that is widely consumed by the community. Tofu is susceptible to damage so manufacturers know often add preservatives such as formaldehyde. Formaldehyde or known as formalin is not included in the list of food additives as they are toxic and harmful to human health. This study aims to determine the decrease in formalin content in tofu using the addition of white turmeric. The method used by spectrophotometry with chromatropic acid as reagent and absorbance is measured at a wavelength of $570 \mathrm{~nm}$. Based on the research results obtained formalin level on tofu before added white turmeric equal to $10.279 \mathrm{ppm}$. After addition of white turmeric solution with concentration $2.5 \%$; $5 \%$ and $7.5 \%$, respectively with soaking for 5 minutes, 10 minutes and 15 minutes obtained the largest decrease of formalin at $7.5 \%$ concentration for 15 minutes at $62.8 \%$. From these results it can be concluded that with the addition of white turmeric can reduce formalin in tofu.
\end{abstract}

Keywords : Tofu, Formaldehyde, White Turmeric, Spectrophotometry

\section{INTRODUCTION}

Tofu as one of the foods processed soybean has been widely recognized and favored by the people of Indonesia (Supriatna, 2007). The result of research Karyasa (1993), obtained data that $10 \%$ of Indonesian population consume tofu as much as 100 gram per day. Tofu is a type of traditional food that is widely consumed because the price is relatively cheap and has a high nutrient content, especially protein, which is 10.9 grams per 100 grams of tofu (Mahmud, et al., 1990). In addition, tofu also has a high water content of about $70-85 \%$, so easy to experience bacterial decay caused (Harmayanti, et al., 2009).

In order to know the old shelf life, some manufacturers use chemical additives as preservatives (Aprlianti, et al., 2007). Preservatives are often added to serve as disinfectants such as chlor and formalin (formaldehyde). The addition of formalin in tofu is usually done when the tofu is ready to be sold by soaking the tofu with water that has been added formalin (Suparyanto, 2011). Formalin is widely used as a preservative because of its ability to inhibit microbial growth, so formalin can be used as an effective disinfectant against vegetative, fungal or viral bacteria (Reynold, 1982). 
Formalin is toxic and harmful to human health so it is not included in the list of food additives (Cahyadi, 2009). The use of formalin has been regulated by Permenkes RI No. 1168/Menkes/Per/X/1989, that formalin is one of the additional ingredients prohibited for use in food.

Formalin is commonly used as a preservative of corpses and bebagai kinds of non-food industrial materials (Wulan, 2015). The formalin safe threshold in the body defined by WHO is 1.0 milligrams per liter ( $1 \mathrm{ppm})$. While those who may enter the body in the form of food for adults is $1.5 \mathrm{mg}$ higga $4 \mathrm{mg}$ per day (Hastuti,. 2010). Toxiform effects caused by formalin can cause damage to the liver, and disorders of the central nervous system, cancer and leukemia (Alsuhendra and Ridawati, 2013).

Research to reduce the level of formalin in foodstuffs has been done, including using 5\% vinegar solution in fresh fish (Hapsari, A., 2010), with warm water on wet noodles (Budiarti, et al., 2009), boiling with hot water in tofu (Muntaha, et al., 2015), soaking with salt water in salted fish (Raihan, 2003), and using galangal in white shrimp (Jannah, et al., 2014).

The analysis of formalin levels can be done by several methods such as titrimetric method (Artha, 2007), colorimetry (Aprilianti, et al., 2006), reflectometry and visible spectrophotometry (Sudjarwo, et al., 2013). This study aims to decrease formalin in tofu by the addition of white turmeric solution using spectrophotometric method. White turmeric is selected because white turmeric contains saponin active compound which can be used to reduce formalin compounds. In addition, turmeric is known as flavoring and neutralizing the smell of rancid that is often used as an additional ingredient in cooking (Said, 2007). Turmeric also has properties can cure various diseases, including diabetes mellitus, typhoid, dysentery, whitish pain and menstruation is not smooth (Putra, 2015).

\section{MATERIALS AND METHODS Material}

All reagents and chemicals used were of analytical grade and all solutions were prepared from double distilled water. Chromatropic acid was obtained from Sigma-Aldrich (China), sulfuric acid, whatman No. 41 filter paper, white turmeric and tofu taken directly from the tofu seller in Gresik city.

\section{Instruments}

Spectrophotometer UV-1600 PC (singgle beam), with $1 \mathrm{~cm}$ matched quartz cells was used for absorption measurement, analytical balance, hot plate, magnetic stirer, and a set of glassware.

\section{PROCEDURE}

Reagents and solutions

Working Formail solution (222 ppm)

Formalin solution (222 ppm) was prepared by by diluting $6.0 \mathrm{~mL}$ of formalin $3.7 \%$ to a 1000 $\mathrm{mL}$ double distilled water in a volumetric flask. 


\section{Chromatropic acid $0.5 \%$}

This solution was prepared by dissolving $0.5 \mathrm{~g}$ of chromatropic acid disodium in double distilled water and adding the double distilled water to $100 \mathrm{~mL}$ in a volumetric flask.

\section{Blank reagent}

The blank reagent was prepared by dissolving 1,2 $\mathrm{ml}$ of chromatropic acid $0.5 \%$ and added $6.0 \mathrm{ml}$ of concentrated $\mathrm{H}_{2} \mathrm{SO}_{4}$ then shaken and allowed to stand for 10 minutes. Furthermore, the solution is added double distilled water until the boundary marks are then shaken until homogeneous.

\section{Turmeric solution}

Turmeric white peeled and washed and then shredded. Turmeric is squeezed and filtered using filter paper to obtain turmeric extract. Furthermore turmeric extract is taken as much as $2.5 \mathrm{ml} ; 5.0 \mathrm{ml}$ and $7.5 \mathrm{ml}$ and put into a $100 \mathrm{~mL} 100 \mathrm{~mL}$ flask. Each of the extracts was added double distilled water to the limit mark and shaken until homogeneous.

\section{Sample Preparation}

Tofu that does not contain formalin washed out and then soaked with a solution of formalin $222 \mathrm{ppm}$ for 1 hour. Tofu that has been soaked using formalin solution then drained and weighed as much as 25 grams. Tofu added turmeric solution each with concentration of $0 \%$ (control), 2.5\%, 5\%, and 7.5\% then left for 5 minutes, 10 minutes, and 15 minutes. Next it is smoothed using porcelain mortar and then put it in a beaker glass with the addition of $50 \mathrm{~mL}$ of double distilled water. Stirred tofu solution using stirer and filtered using Whatman No. 41. The obtained tofu filtrate is fed into a $100 \mathrm{ml}$ measuring flask and diluted with double distilled water to the limit marker.

\section{Preparation of callibration curve}

Standard solution of formalin was prepared with a range concentration of 2.2-11.1 ppm. Taken sequentially $0.25 \mathrm{ml} ; 0.5 \mathrm{ml}, 0.75 \mathrm{ml} ; 1.0 \mathrm{ml}$; and $1.25 \mathrm{ml}$ of a $222 \mathrm{ppm}$ formalin solution were transferred into a series $25 \mathrm{ml}$ volumetric flask. Each solution was added $1.2 \mathrm{ml}$ of chromatropic acid $0.5 \%$ and $6.0 \mathrm{ml}$ of concentrated $\mathrm{H}_{2} \mathrm{SO}_{4}$, shaken and allowed to stand for $10 \mathrm{~min}$. Furthermore, standard solution is added double distilled water to the limit marker and shaken until homogeneous and the absorbance was measured at $570 \mathrm{~nm}$ against the reagent blank.

\section{Determination of formalin}

The formalin level was determined using Cahyadi's proposed method (2009), with slight modification. The sample solution $(1.0 \mathrm{~mL})$ was transferred in a $25 \mathrm{ml}$ volumetric flask and added $1.2 \mathrm{ml}$ of $0.5 \%$ chromatropic acid and $6 \mathrm{ml}$ of concentrated $\mathrm{H}_{2} \mathrm{SO}_{4}$ then shaken and allowed to stand for 10 minutes. The solution is added double distilled water to the limit mark and shaken until homogeneous. Furthermore the standard solution is read for absorbance with a spectrophotometer at a wavelength of $570 \mathrm{~nm}$.

\section{RESULTS AND DISCUSSION Maximum Wavelength}

Before to the analysis of formalin on tofu, the maximum wavelength was determined. It aims to obtain the wavelength that has the maximum sensitivity and absorbance. Measurements were made by reading the absorbance of formalin standard solution using UV-1600 PC 
sectrophotometer at wavelength $555-585 \mathrm{~nm}$. The measurement results obtained maximum absorbance at $570 \mathrm{~nm}$. This wavelengths is used for the determination of formalin on the tofu sample.

\section{Calibration Curve}

The calibration curve of formalin standard solution was obtained good a linear curve according to Lambert-Beerlaw in the concentration range $2.2-11.1 \mathrm{ppm}$. Based on the curve obtained regression equation $\mathrm{y}=0,043 \mathrm{x}+0,026$ and the correlation coefficient was found from the linear regression equation $r=0.999$, which indicated an excellent linearity (Figure 1).

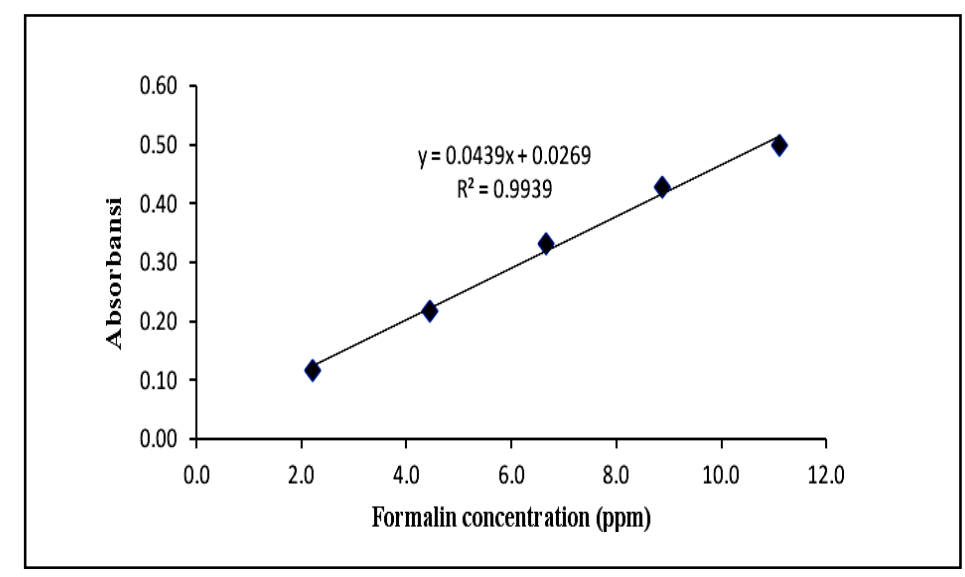

Figure 1. Calibration curve of formalin standard solution

\section{Levels of Formalin}

Based on the research of formalin content analysis on tofu before being treated with soaking with white turmeric solution obtained an average yield of $10.279 \mathrm{ppm}$. Formaldehyde levels subsequently decreased significantly after soaking using white turmeric solution with a concentration variation; $0 \% ; 2.5 \% ; 5 \%$; and $7.5 \%$ were soaked for 5 minutes, 10 minutes and 15 minutes at each concentration. At $0 \%$ concentration the tofu sample was only soaked using distilled water as a control. Formaldehyde levels in tofu prior to the addition of white turmeric solution are listed in Table 1.

Table 1. Levels of formalin on tofu before addition of white turmeric

\begin{tabular}{ccccc}
\hline Sample of tofu & \multicolumn{3}{c}{ Levels of formalin (ppm) } & $\begin{array}{c}\text { Average levels of } \\
\text { formalin (ppm) }\end{array}$ \\
\cline { 2 - 4 } & 1 & 2 & 3 & 10.279 \\
\hline
\end{tabular}

In the tofu treatment soaked using distilled water or concentration of $0 \%$ white turmeric solution for 5 minutes, 10 minutes, and 15 minutes respectively obtained an average formalin level of $8.860 \mathrm{ppm} ; 5.698 \mathrm{ppm}$ and $5.605 \mathrm{ppm}$. In the addition of white turmeric solution with a concentration of $2.5 \%$ which was soaked for 5 minutes, 10 minutes and 15 minutes 
respectively obtained an average formalin level of $8.178 \mathrm{ppm} ; 5.411 \mathrm{ppm}$ and 5.085 . At 5\% concentration for $5 \mathrm{~min}, 10 \mathrm{~min}$ and $15 \mathrm{~min}$ got $5.922 \mathrm{ppm} ; 4.093$ and 4,093. Immediate at $7.5 \%$ concentration for 5 minutes, 10 minutes and 15 minutes obtained $5.628 \mathrm{ppm}$ respectively; $4.488 \mathrm{ppm}$ and $4.000 \mathrm{ppm}$. Formaldehyde levels in tofu after the addition of white turmeric solution are listed in Table 2.

Table 2. Levels of formalin on tofu after the addition of white turmeric solution

\begin{tabular}{|c|c|c|c|c|c|}
\hline \multirow{2}{*}{$\begin{array}{c}\text { Concentration } \\
\text { of turmeric }\end{array}$} & \multirow{2}{*}{$\begin{array}{l}\text { Soaking time } \\
\text { (minutes) }\end{array}$} & \multicolumn{3}{|c|}{ Levels of formalin (ppm) } & \multirow{2}{*}{$\begin{array}{l}\text { Average levels of } \\
\text { formalin (ppm) }\end{array}$} \\
\hline & & 1 & 2 & 3 & \\
\hline \multirow{3}{*}{$0 \%$} & 5 & 8.837 & 8.884 & 8.860 & 8,860 \\
\hline & 10 & 5.698 & 5.698 & 5.698 & 5,698 \\
\hline & 15 & 5.605 & 5.605 & 5.605 & 5,605 \\
\hline \multirow{3}{*}{$2,5 \%$} & 5 & 8.186 & 8.163 & 8.186 & 8.178 \\
\hline & 10 & 5.419 & 5.395 & 5.419 & 5.411 \\
\hline & 15 & 5.070 & 5.093 & 5.093 & 5.085 \\
\hline \multirow{3}{*}{$5 \%$} & 5 & 5.930 & 5.907 & 5.930 & 5.922 \\
\hline & 10 & 4,744 & 4,744 & 4,744 & 4,744 \\
\hline & 15 & 4.093 & 4.093 & 4.093 & 4,093 \\
\hline \multirow{3}{*}{$7,5 \%$} & 5 & 5.628 & 5.628 & 5.628 & 5,628 \\
\hline & 10 & 4.488 & 4,488 & 4.488 & 4,488 \\
\hline & 15 & 3.977 & 4.000 & 4.023 & 4.000 \\
\hline
\end{tabular}

Based on Table 2, it can be seen that the addition of turmeric solution in tofu gives a significant effect on formalin levels. This proved to be a decrease in formalin levels in the tofu before being treated by immersion and after soaking using distilled water and white turmeric solution. The occurrence of decreased levels of formalin in tofu along with the increasing concentration of white turmeric solution added. The graph of decreased levels of formalin on tofu after the immersion treatment is shown as in Figure 1.

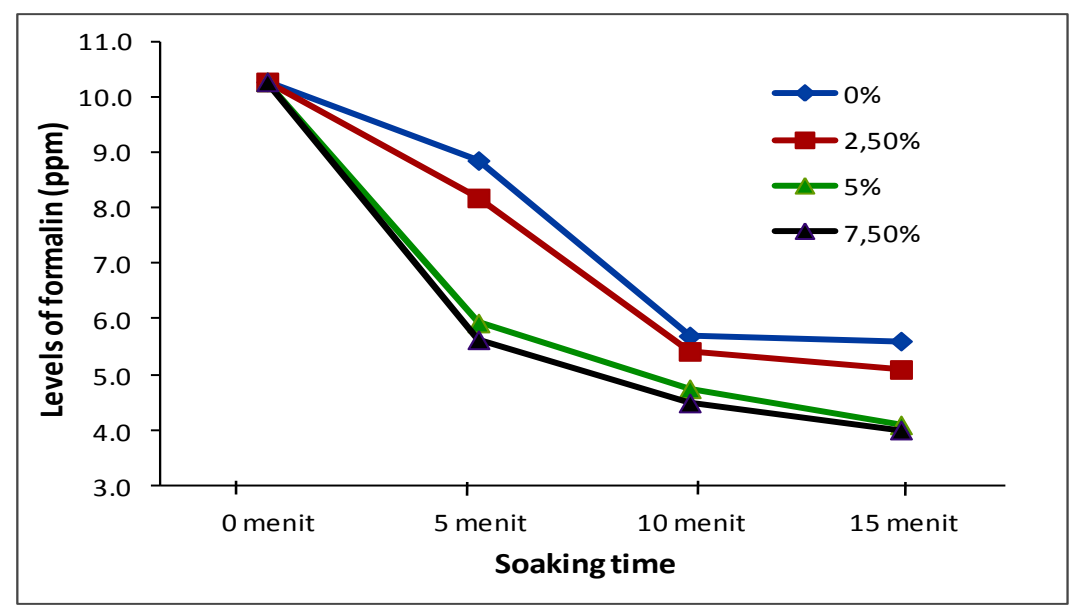

Figure 1. Graph of decreased levels of formaldehyde in tofu 
Soaking tofu using distilled water for 5 minutes, 10 minutes and 15 minutes in a row can decrease formalin levels by $14.2 \% ; 45.8 \%$ and $46.7 \%$. While the addition of white turmeric solution obtained the largest decrease in formalin content in the tofu with a concentration of $7.5 \%$ for 5 minutes; 10 minutes and 15 minutes at $46.5 \% ; 57.9 \%$ and $62.8 \%$. The ratio of the decrease in formalin content in tofu by the addition of white turmeric solution and the addition of distilled water is shown in Figure 2.

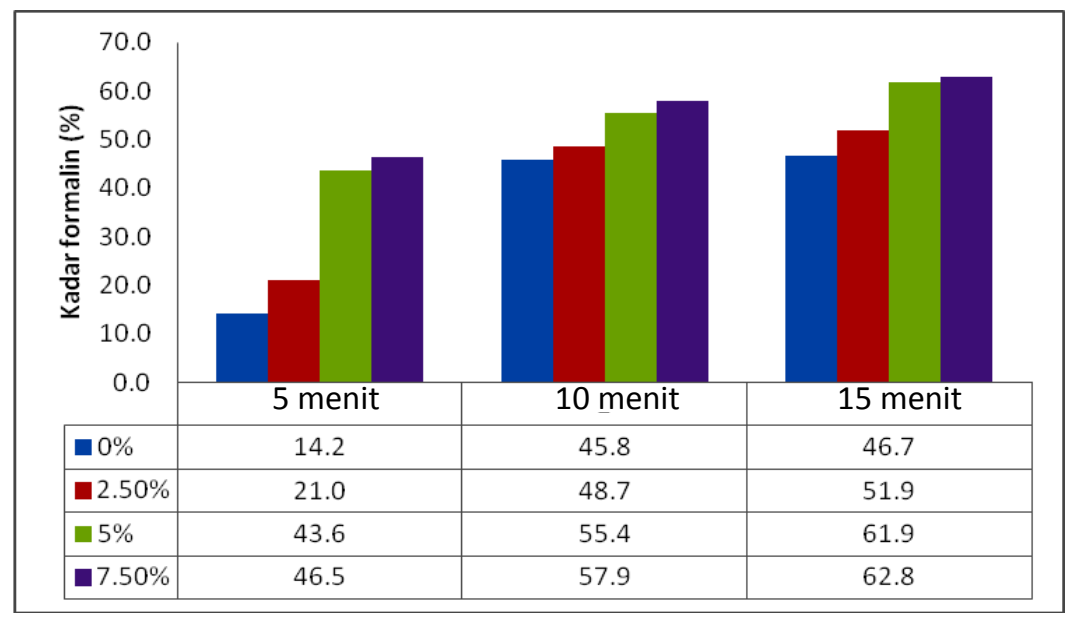

Figure 2. Comparison of formalin decrease in tofu with control

The amount of formalin content that can be removed in the tofu depends on the type of bond between formalin and protein in the tofu. According to Kieman (2000), formalin can bind to proteins in foodstuffs in the form of reversible methyl-alcohol and cross-linked proteins (protein-crosslink) are irreversible. The methyl-alcohol bond form is easily broken down in the presence of a compound acting as a provider of $\mathrm{H}^{+}$(polar) ions as well as compounds acting as emulsifiers or surfactants.

Distilled water can decrease the level of formaldehyde in tofu because polar water has the ability to attract some of the formalin compounds that are also polar in tofu. Whereas white turmeric solution can reduce the level of formalin in the tofu because of chemical reactions between saponin active compound contained in turmeric with formalin in tofu. This is according to the results of research Jannah et al., (20007), which proves formalin in white shrimp can be reduced by saponins contained in alpinia galangal.

(1). Protein $-\mathrm{H}+\underset{\text { (Formalin) }}{\mathrm{HCHO}} \longrightarrow$ Protein $-\mathrm{HCHOH}$

(2). Protein $-\mathrm{HCHOH}+\mathrm{H}-$ Protein $\rightarrow$ Protein $-\underset{\mathrm{H}}{\mathrm{C}}-$ protein $+\mathrm{H}_{2} \mathrm{O}$

(3). Protein $-{ }_{1}^{\mathrm{C}}-$ Protein $+\mathrm{H}_{2} \mathrm{O}+$ Saponin $\longrightarrow$ Protein $-\mathrm{H}+$ HCHO--Saponin-- $\mathrm{H}_{2} \mathrm{O}$

Figure 3. Allegations mechanism of formalin withdrawal attached to proteins in the tofu. 
The saponin compound is an amphipic glycoside having a lipophilic and hydrophilic group, so it can act as an emulsifier (Gunawan and Mulyani., 2004). The mechanism of formalin withdrawal, ie when the tofu containing formaldehyde is soaked with turmeric solution, the saponin compound will emulate formaldehyde binding to proteins in the tofu. Formalin will be attracted by the saponins contained in the turmeric solution to form micelles. The part of the polar (hydrophobic) group will interact with the polar water so that the formaldehyde can dissolve together with water (Amran, 2008). This is due to the presence of two polar and non-polar groups in saponins that have the ability to emulsify water and formaldehyde.

\section{CONCLUSION}

Formaldehyde content in tofu can be reduced using saponins contained in white turmeric. The higher concentration of white turmeric solution added the greater the decrease of formalin levels obtained. In this research, the highest level of formalin content in tofu was found in addition of turmeric concentration of $7.5 \%$ soaked for 15 minutes at $62.8 \%$.

\section{ACKNOWLEDGMENT}

The author would like to thank the Laboratory of Delima Husada College of Health Analysts by the availability of the equipment and reagents for the conduct of this research.

\section{REFERENCES}

[1] Alsuhendra dan Ridawati, 2013, Bahan Toksik dalam Makanan, Penerbit Rosda, Jakarta, 40-47

[2] Amran, 2008, Pengaruh Garam-Garam Nitrat terhadap Konsentrasi Miselisasi Kritis (CMC, Critical Micellization Concentration) Saponin, J. Saintek, 11(1), 11-18.

[3] Aprilianti, Ayudiah., Ma'ruf, A., Fajarini, Z.N., Purwanti. D., 2007, Studi Kasus Penggunaan Formalin pada Tahu Takwa di Kotamadya Kediri, Program Kreativitas Mahasiswa, Universitas Muhammadiyah Malang, Malang.

[4] Artha, E., 2007, Pemeriksaan Kandungan Formaldehid pada Berbagai Jenis Peralatan Makan Melamin di Kota Medan, Skripsi, Universitas Sumatera Utara, Medan.

[5] Budiarti, Aqnes., Supriyanti., Musinah, S., 2009, Pengaruh Perendaman dalam Air Hangat terhadap Kandungan Formalin pada Mie Basah dari Tiga Produsen yang Dijual di Pasar Johar Semarang, J. Ilmu Farmasi dan Farmasi Klinik, 6(1), 1-6.

[6] Cahyadi, W., 2009, Analisis dan Aspek Kesehatan Bahan Tambahan Pangan, Penerbit Bumi Aksara, Jakarta, 71-76.

[7] Gunawan, D dan Mulyani, S., 2004., ilmu obat alam (Farmakognosi), Penebar Swadaya Jakarta.

[8] Hastuti, S., 2010, Analisis Kualitatif dan Kuantitatif Formaldehid pada Ikan Asin di Madura, J. Agrointek, 4(2), 11-18

[9] Hapsari, A., 2010, Pengaruh Perendaman Dengan Larutan Cuka 5\% Dan Air Panas Terhadap Pelepasan Kadar Formalin Pada Cumi-Cumi, Ikan Gembung, Udang Dan Ikan Dencis Secara Secaraspektrofotometri Sinar Tampak, Skripsi, Universitas Sumatera Utara, Medan. 
[10] Harmayani, E., Rahayu, E.S., Sari, C.A., Marwati, T., 2009, Pemanfaatan Kultur Pediococcus acidilactici F-11 Penghasil Bakteriosin sebagai Penggumpal pada Pembuatan Tahu, J. Pascapanen, 6(1), 10-20

[11] Jannah, M., Ma'ruf, W.F., and Surti, T., 2014, Efektifitas Lengkuas (Alpinia Galanga) Sebagai Pereduksi Kadar Formalin pada Udang Putih (Panaeuus merguiensis) Selama Penyimpanan Dingin, J. Pengolahan dan Biotek. Hasil Perikanan, 3(1), 70-79.

[12] Karyasa, I.W. 1993, Bangga Makan Tahu Tempe, Forum Diskusi Indonesia-Berlin, Jakarta.

[13] Kieman, J.A., 2000, Formaldehyde, Formalin, Paraformaldehyde, and Glutaraldehid, What They Are and What They Do, Microscopy Today, University Of Western Ontario, London, 8-12.

[14] Mahmud, M.K., D.S. Slamet., R.R. Apriantono., dan Hermana., 1990, Komposisi Zat Gizi Pangan, Depkes. RI, Direktorat Bina Gizi Masyarakat dan Pusat Penelitian dan Pengembangan Gizi, Jakarta, 34-36.

[15] Muntaha, A., Haitami, Hayati, N., 2015, Perbandingan Penurunan Kadar Formalin pada Tahu yang Direbus dan Direndam Air Panas, Medical Laboratory Technology Journal, 1(2), 84-90

[16] Putra, W.S., 2015, Kitab Herbal Nusantara: Aneka Resep \& Ramuan Tanaman Obat untuk Berbagai Gangguan Kesehatan, Penerbit Kata Hati, Yogyakarta, 25-31.

[17] Raihan, C.F., 2003, Pengaruh waktu perendaman terhadap serapan formalin dan proses deformalisasi ikan asin Jambal Hasil Proses Penggaraman kering, Skripsi, Jurusan Kimia FMIPA ITS, Surabaya

[18] Reynold, James E.F., 1982, Martindale the Extra Pharmacopoeia, $28^{\text {th }}$ edition, The Pharmaceutical Press, London, 115-117.

[19] Said, A., 2007, Khasiat \& Manfaat Kunyit, Penerbit Sinar Wadja Lestari, Jakarta.

[20] Sudjarwo, Darmawati, A., Hariyanti, A.W., 2013, Penetapan Kadar Formalin dalam Ayam Potong yang Diambil di Pasar Tradisional Surabaya Timur, J. Universitas Airlangga, 2(2), 13-19.

[21] Suparyanta, A., 2011, Teknologi Pengawetan Makanan, Penerbit PT Maraga Borneo Tarigas, Singkawang, 33-37.

[22] Supriatna, D., 2007, Membuat Tahu Sumedang, Penerbit Penebar Swadaya, Jakarta.

[23] Wulan, S.R., 2015, Identifikasi Formalin pada Bakso dari Pedagang Bakso di Kecamatan Panakukkang Makassar, Skripsi, Universitas Hasanuddin, Makassar.

J. Islamic Pharm., an open access journal

ISSN : 2527-6123 